\title{
PKM KELOMPOK UBI BETE DI DESA RAANAN BARU KECAMATAN MOTOLING BARAT KABUPATEN MINAHASA SELATAN
}

\author{
Nontje Marie Sangi \& Herni Kumaat \\ Fakultas Teknik, Universitas Negeri Manado (UNIMA)
}

\begin{abstract}
Abstrak
Meningkatkan harga jual ubi bete hasil pertanian petani dan daya saing produk kuliner berbagai varian kue. Alih teknologi dalam proses pengolaan dari bahan baku ubi bete menjadi tepung sehingga diversifikasi varian kuliner melalui tepung ubi bete. Produk kuliner seperti: bronis, cake, dan jari-jari dari olahan tepung ubi bete mampu bersaning dengan produk sejenis yang ada di pasaran. Tujuan PKM ini, (1) Mengembangkan verivikasikan bahan baku dari petani kelompok tani ubi bête di desa Raanan Baru kecamatan Motoling Barat kabupaten Minahasa Selatan, (2) Meningkatkan ketrampilan pada ibu-ibu dalam berkreativitas produk keripik dari bahan komoditi ubi bête, di desa Raanan Baru kecamatan Motoling Barat kabupaten Minahasa Selatan. Hasil kegiatan PKM bahwa respons konsumer keripik dari produk "RB" yang dapat dinyatakan berhasil baik dari segi profit penjualan (laba) maupun kelarisan produk.
\end{abstract}

Kata Kunci: Ubi bete, teknologi, keripik..

\section{PENDAHULUAN}

Masyarakat desa Raanan Baru, Kecamatan Motoling Barat, Kabupaten Minahasa Selatan, yang menjadi mitra dengan pelaksana kegiatan pengabdian pada masyarakat merupakan bagian dari salah satu kelompok potensial penghasil olahan Ubi bete. Penduduk Desa Raanan Baru pada umumnya sebagai petani ubi bête secara turun temurun. Masyarakat secara tradisional mengelola lahan pertanian bersama menanam ubi bete dengan target hasil optimal. Hasil tanaman ubi bête di pasok ke Manado, dan ke kota lainnya oleh pengumpul (tibo-tibo) tanpa diolah. Umumnya masyarakat mengkonsumsi ubi bete (talas) hanya pada kondisi tertentu saja, ketika musim paceklik yang berimbas pada menurunnya daya beli masyakarakat atau ketika produksi beras dan jagung tidak mencukupi kebutuhan pangan. Rendahnya minat masyarakat mengkonsumsi ubi bete (talas) disebabkan pandangan yang masih rendah terhadap komoditi ini. Masih banyak masyarakat merasa malu dan gengsi untuk menyajikan ubi bete sebagai hidangan sehari-hari. Sehingga ubi bete sebagai bahan pangan memiliki derajat yang rendah di mata masyarakat.

Koordinator mitra dalam pelaksanaan kegiatan PKM adalah ibu Oknie Rorimpandey sebagai kordinator kelompok tani penanam (budidaya) ubi bête dan penjual komoditi pangan ubi bête, yang beranggotakan 5 orang. Penanaman atau pembudidayaan tanaman ubi bête yang dilakukan oleh kelompok tani, masih secara konvensional yaitu penanaman maupun penjualan masih secara tradisional. Dari hasil pertemuan dan wawancara antara 
kelompok tani dengan team pelaksana pengabdian pada masyarakat dari UNIMA menawarkan untuk penanaman secara berkala agar stok komoditi pangan ini tidak akan habis dan penjualan dilakukan secara terkordinasi untuk menghindari pembeli (tibo-tibo) yang mematok harga yang paling rendah alias tidak manusiawi, dan direspons oleh kelompok tani dengan sangat antusias.

Kordinator mitra pelaksanaan kegiatan $\mathrm{P}_{\mathrm{K}} \mathrm{M}$ oleh ibu Frelly Supit sebagai kordinator kelompok tani produksi kripik, tepung, dan brownies cake/tart, yang dilakukan secara sederhana yaitu menggunakan alat sederhana. Dari hasil wawancara antara kelompok tani dengan team pelaksana kegiatan $\mathrm{P}_{\mathrm{K}} \mathrm{M}$ dari UNIMA menawarkan beberapa produk untuk dijadikan usaha industry kreatif yaitu pembuatan kripik, tepung sebagai bahan dasar adonan kue, brownies cake/tart dengan menggunakan peralatan sederhana, maupun teknologi canggih untuk dapat meningkatan produksi. Dari hasil pertemuan dan diskusi antara kelompok mitra dengan team pelaksana kegiatan dari UNIMA, maka mitra kelompok tani ini merespons dengan sangat antusias.

Permasalahan yang dialami mitra dapat di kemukakan sebagai berikut:

1. Kurangnya pengetahuan tentang mengoptimalkan alat pengolah secara teknologi sederhana maupun teknologi canggih;
2. Kurangnya modal untuk membeli peralatan yang sesuai untuk mengembangkan industri rumah tangga;

3. Kurangnya pengetahuan maupun pemahaman tentang metode dan teknik pengolahan UBI BETE yang bervariasi;

4. Belum mengetahui nilai gizi yang terkandung dalam ubi bete; dan

5. Terbatasnya informasi dan pengetahuan tentang penganekaragaman pengolahan produk dari ubi bete.

Berdasarkan indikasi masalah yang ada perlu diberi penyuluhan dan pelatihan kepada Ibu-ibu di desa Raanan Baru kecamatan Motoling Barat, maka pilihan yang akan dikembangkan pada produk ubi bête adalah bagaimana kelompok masyarakat dapat membuat keripik berbagai varian.

\section{KAJIAN LITERATUR}

Metode pengolahan makanan adalah suatu proses menangani bahan makanan dari mentah (dasar) menjadi bahan makanan siap saji yang dalam prosesnya bisa terjadi penerapan panas maupun tidak. sedangkan memasak adalah suatu proses penerapan panas pada bahan makanan dari mentah menjadi matang dengan tujuan tertentu (Minantyo, H. 2011:124).

Metode pada proses pengolahan dibagi 3 (tiga) kategori besar secara umum, dan yang 1 (satu) merupakan proses campuran: 1) panas basah (moist heat); 2) panas kering (dry heat); 3) panas dengan minyak (oil heat); dan 4) panas campuran basah dan 
kering (mix heat). Pada pengolahan kue kering, sering menggunakan teknik pengolahan panas kering. Teknik pengolahan panas kering yaitu: 1) baking, mengepan atau memasak bahan makanan dalam oven dengan panas segala arah; 2) grilling/ broilling (membakar); 3) grilling adalah memasak bahan makanan di atas lempengan besi panas (gridle) yang diletakkan di atas perapian, suhu yang dibutuhkan sekitar 292 ${ }^{\circ} \mathrm{C}$, panas ini biasanya bisa dari arang, batubara, elpiji atau alat elektrik lainnya; 4) broilling adalah teknik memasak bahan makanan di atas pan dadar (teflon), dalam teknik ini perlu diberikan sedikit minyak; dan 5) roasting adalah teknik memasak bahan makanan dengan cara memanggang bahan makanan dalam bentuk besar di dalam oven.

\section{METODE PELAKSANAAN}

\section{Langkah Pelaksanaan Program}

Adapun langkah-langkah pelaksanaan program PKM ini sebagai berikut:

1. Persiapan bahan baku, dimulai dari pembelian bahan baku berupa ubi yang baik dan segar dari semua varietas ubi bete yang aman dikonsumsi, didapat dari petani ubi bete Desa Raanan Baru. Selanjutnya bahan baku yang telah diperoleh kemudian di sortasi untuk mendapatkan bahan baku yang dianggap baik untuk diolah;

2. Pengolahan, merupakan kegiatan dimulai dari proses pengupasan bahan baku, pencucian, pengirisan, hingga bahan baku siap untuk dilakukan pengolahan;

3. Pembuatan keripik, merupakan rangkaian proses pengolahan bahan mentah dari ubi bete, selanjutnya diolah menjadi keripik ubi bete yang siap untuk dikonsumsi. Caranya, kupas ubi bete lalu dicuci dengan air sampai bersih, iris ubi bete yang sudah bersih membentuk bulat tipis-tipis. Rendam ubi bete dalam air yang sudah dicampur dengan kapur sirih selama 2 jam, angkat tiriskan. Selanjutnya, jemur ubi bete dibawah terik matahari sampai benar-benar kering. Campurkan ubi bete dengan bumbu yang sudah dihaluskan lalu siap digoreng dalam minyak panas sampai matang. Kemudian akan diadakan beberapa uji untuk membuktikan apakah keripik ubi bete ini baik untuk dikonsumsi di laboratorium maupun secara langsung di masyarakat. Responden sebagai konsumer keripik produk "RB" di minta tanggapan sehingga akan diketahui respon masyarakat terhadap produk keripik;

4. Paket teknologi produk dan pengemasan, dilakukan untuk mengetahui tentang teknologi produk yang dihasilkan, perkiraan daya simpan produk yang dihasilkan dan teknologi pengemasan yang sesuai dengan produk guna mempertahankan mutu dan kualitas produk. Teori yang diberikan berkaitan dengan sifat fisik dan karakteristik 
bahan, pengetahuan tentang pengemasan dan labeling produk; dan

5. Promosi dan pemasaran, setelah keempat paket kegiatan di atas selesai dilaksanakan maka akan dilakukan promosi dan pemasaran yang akan dilakukan dengan beberapa cara yaitu langsung dijual kepada konsumen dan toko-toko yang banyak dikenal masyarakat atau toko-toko yang telah berkompeten dalam bidang pendistribusian makanan serta langsung menuju masyarakat sasaran yang telah ditentukan. Berdasarkan pola manajemen usaha keripik dari kelompok tani "RB" tersebut dapat dilihat prospek pengembangan usaha sebagai wirausaha kuliner, layak untuk dilanjutkan.

\section{Tahapan Evaluasi Kegiatan}

Untuk memantau kemajuan proram kerja, evaluasi dilakukan melalui tahapan sebagai berikut:

1. Evaluasi awal program, diarahkan pada penilaian efektifitas pelaksanaan kerja tim, dan terhadap hasil yang diperoleh pada awal kegiatan. Juga terhadap kendala-kendala yang dihadapi oleh tim pelaksana serta menganalisis tahap awal atas data dan informasi yang terjaring. Apabila ditemukan masih ada kelemahan dan kendala, akan dibahas bersama dalam tim untuk kemudi-an ditindaklanjuti tahapan selanjutnya;
2. Evaluasi program pelaksanaan, bertujuan untuk mengkaji tingkat efektivitas pelaksanaan program dalam mencapai tujuan dan sasaran dengan cara melakukan pengamatan langsung proses pelaksanaan kegiatan dan hasil yang diperoleh berdasarkan berbagai pendekatan yang akan dilakukan;

3. Evaluasi akhir program, diarahkan pada pengkajian terhadap efektivitas pelaksanaan program dalam mencapai tujuan dan sasaran. Gambaran keberhasilan program ini didasarkan pada kriteria: 1) dinyatakan berhasil bila hasil akhir di atas $80 \%$ dari tujuan dan sasaran yang ingin dicapai; 2) dinyatakan kurang berhasil apabila pencapaian skor hasil 50-80 \%; dan 3) tidak berhasil apabila skor kurang dari 50 \%. Namun kemungkinan untuk kurang berhasil maupun tidak berhasil akan sangat kecil karena pada evaluasi awal telah dilakukan tindakan pemantapan program.

\section{HASIL DAN PEMBAHASAN}

\section{Hasil Pelaksanaan Kegiatan}

Kegiatan PKM dilaksanakan dengan cara pengembangan usaha kuliner berbasis bahan baku lokal seperti ubi bete. Bentukan kelompok wirausaha melalui kemitraan dengan masyarakat Desa Raanan Baru Kecamatan Motoling Barat, menyepakati kerjasama dengan pihak LPPM UNIMA untuk pengembangan usaha keripik berbagai varian berbasis bahan baku ubi bete 
setempat. Pemantapan Tim PKM dengan kelompok mitra setelah difasilitasi peralatan produk olahan, maka proses penggarapan kegiatan olahan menjadi produk keripik dilakukan mulai bulan April sampai dengan Juni 2017. Hasil olahan ubi bete menjadi keripik dapat dilihat seperti pada gambar dibawah ini.

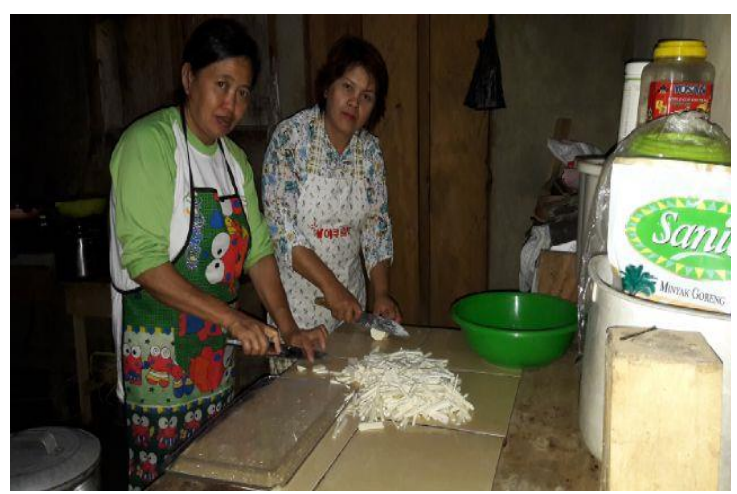

Gambar 1. Pengolahan ubi bete menjadi keripik.

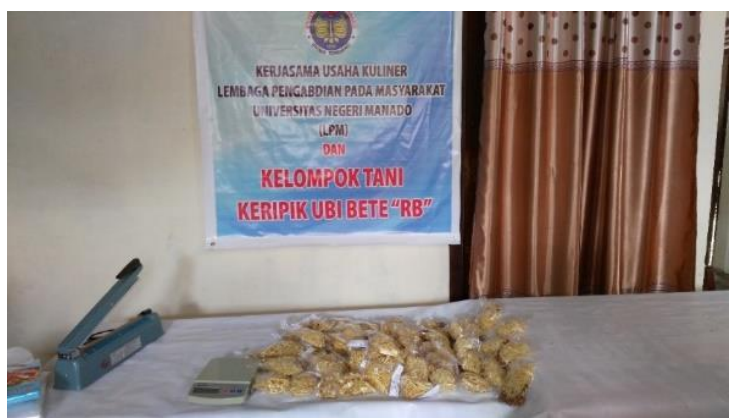

Gambar 2. Hasil olahan ubi bete menjadi keripik.

\section{Analisis Usaha}

Dalam 1 periode produksi keripik ubi bete akan digunakan bahan baku ubi bete sebanyak $20 \mathrm{~kg}$. Dari $20 \mathrm{~kg}$ bahan mentah ubi bete akan diperoleh sekitar $16 \mathrm{~kg}$ keripik ubi bete. Produk akan dikemas dalam bentuk kemasan dengan netto: 250 gram $(1 / 4 \mathrm{~kg})$ sehingga dari $16 \mathrm{~kg}$ produk yang dihasilkan akan diperoleh 64 bungkus dengan berat 250 gram. Harga untuk 1 bungkus keripik dengan berat 250 gram adalah Rp. 5.000,- sehingga akan diperoleh pendapatan kotor di setiap periode adalah sebesar 64 bks x Rp.5.000,- = Rp.320.000,dan untuk 20 kali produksi didapatkan jumlah kotor Rp.6.400.000. Adapun keseluruhan modal yang dikeluarkan di awal kegiatan usaha (PKM),

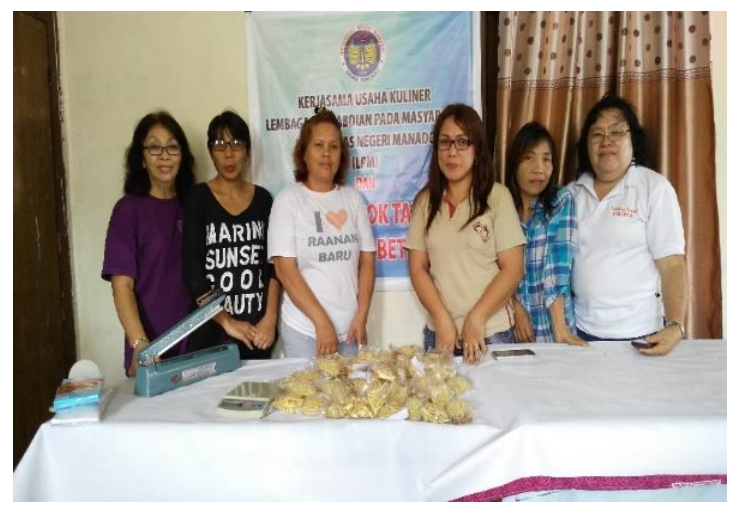

Gambar 3. Dokumentasi tim pelaksana kegiatan dan kelompok mitra.

\section{Tanggapan Responden Produk Keripik}

Manajemen usaha dalam wirausaha keripik "RB" menurut tanggapan konsumer dilihat dari segi kemasan rata-rata menyatakan sangat layak untuk dijual. Segi ukuran kemasan rata-rata menyatakan sesuai dengan harganya. Kualitas keripik reta-rata menyatakan memiliki ketahanan produk yang baik dan teksturnya sesuai dengan lidah. Segi Harga yang ditawarkan rata-rata konsumer menyatakan sesuai dengan harga dan terjangkau. Segi citarasa rata-rata konsumer menyatakan sesuai dengan selera dan gurih. Dengan demikian 
produksi keripik sebagai hasil dari olahan kelompok tani masyarakat Desa Raanan Baru Kecamatan Motoling Barat dapat dinyatakan berhasil.

\section{Pembahasan}

Pemanfaatan langsung ubi bete, ada beberapa kendala sebagai bahan baku pangan yaitu timbulnya rasa gatal, rasa terbakar dan iritasi pada kulit, mulut, dan tenggorokan serta saluran cerna saat di konsumsi. Masalah ini disebabkan oleh kalsium oksalat yang ada didalam ubi bete. Untuk menghilangkan dan mengurangi kadar oksalat didalam ubi bete dapat dilakukan perebusan, perendaman dalam air hangat, perendaman dalam larutan garam. Perkecambahan dan fermentasi juga dilakukan untuk menurunkan kadar oksalat terlarut. Salah satu untuk menanggulangi hal tersebut, maka dilakukan pengolahan ubi bete menjadi keripik.

Dengan respons consummer care berhasil baik dari segi profit penjualan maupun kelarisan produk. Hal ini sejalan dengan kegiatan pengabdian oleh Suranta dkk (2016), yang menyatakan dampak adanya kegiatan pengabdian pada masyarakat adalah produksi dapat meningkat baik kuantitas maupun kualitasnya dan manajemen usaha serta pembukuan sederhana telah dapat dilakukan, sehingga penjualan dapat meningkat yang berarti meningkatkan laba UMKM khusunya, umumnya dapat meningkatkan kesejahteraan masyarakat di sekitarnya

\section{KESIMPULAN}

Upaya kemitraan program PKM dengan kelompok masyarakat Desa Raanan Baru Kecamatan Motoling Barat dalam 20 kali produksi terjadi peningkatan laba. Tanggapan konsumer produk keripik "RB" rata-rata menyatakan sesuai selera dan terjangkau harga kemasan. Produk keripik ubi bete sangat diminati masyarakat.

\section{KEPUSTAKAAN}

Darmayasa, I. Nyoman. 2012. Pendidikan dan Pelatihan Manajemen Pengelolaan Usaha UKM Mitra Binaan. Bali: PT. Jasa Raharja (Persero).

Hasibuan, D. S. 2003. Evaluasi Program Pemberian Makanan Tambahan. Universitas Gadjah Mada Yogyakarta.

Suranta, S., Perdana H. D., Syafiqurrahman M. 2016. Usaha Keripik Nabati: Manajemen Usaha dan Proses Produksi. Jurnal Semar, Vol. IV, No. 2.

Minantyo, H. 2011. Dasar-Dasar Pengolahan Makanan. Yogyakarta: Graha ilmu.

Winarno, F. G. 2004. Kimia Pangan dan Gizi. Jakarta: Gramedia Pustaka Utama. 